\title{
Sealing Ability of MTA and Amalgam in Different Root-End Preparations and Resection Bevel Angles: An In Vitro Evaluation Using Marginal Dye Leakage
}

\author{
Letícia Kirst POST ${ }^{1}$ \\ Fábio Garcia LIMA ${ }^{2}$ \\ Cristina Braga XAVIER ${ }^{2}$ \\ Flávio Fernando DEMARCO ${ }^{2}$ \\ Marília GERHARDT-OLIVEIRA ${ }^{3}$ \\ ${ }^{1}$ Dental School, Federal University of Santa Maria, Santa Maria, RS, Brazil \\ ${ }^{2}$ Dental School, Federal University of Pelotas, Pelotas, RS, Brazil \\ ${ }^{3}$ Dental School, Pontifical Catholic University of Rio Grande do Sul, Porto Alegre, RS, Brazil
}

\begin{abstract}
This in vitro study evaluated the effect of different apicoectomy angles, instruments used in root-end preparation, and dental materials used in retrofilling on apical sealing. Root ends were resected at 45 or 90 degrees in 80 single-rooted teeth. For each type of apicoectomy, root-end cavities were prepared with either a round carbide \#2 bur or an S12/90D ultrasonic tip. The root-end cavities in each subgroup (apicoectomy + root-end preparation) were filled with silver amalgam without zinc (Am) or with gray mineral trioxide aggregate -Angelus (MTA), and the specimens were immediately immersed in $0.2 \%$ rhodamine B for $24 \mathrm{~h}$. Sealing was evaluated based on the dyed crosssectional dentin area. Data were analyzed statistically by the Kruskal-Wallis test at $5 \%$ significance level. No group showed complete sealing of root-end areas. The only significant factor affecting microleakage was dental material, with MTA exhibiting less leakage.
\end{abstract}

Key Words: apicoectomy, apical microleakage, dental materials, retrofilling.

\section{INTRODUCTION}

Several factors can jeopardize the success of endodontic treatment. Persistent contamination of the apical region, for example, is an indication for surgery. Retrofilling should seal the apex against diffusion of bacterial products from the root canal system to periradicular tissues (1).

Apicoectomy is an alternative to avoid extractions when endodontic therapy or root canal retreatment fails or is not feasible $(2,3)$. It is an important conservative treatment and an extension of endodontic therapy whose purpose is to preserve the tooth (4).

The appropriate interaction between retrofilling material and retrocavity surface depends not only on the materials' characteristics, but also on the surface conditions at the time of the retrograde filling (5). In order to obtain an adequate sealing after retrofilling, different materials have been indicated, usually amalgam, glass ionomer cement, zinc oxide and eugenol cement, guttapercha and composite resins. In recent years, the mineral trioxide aggregate (MTA) has received crescent interest as a retrograde material with promising results (6).

Different angles and instruments have been used to section the apical root during apicoectomies. A $45^{\circ}$ buccolingual bevel is an option to facilitate the material insertion, and can be indicated when conventional handpiece is used for cavity preparation. However, it could increase the apical leakage because the permeability of the dentin tubules are more exposed by the bevel angle $(2,7)$. In opposite, the ultrasonic instruments appear as an option for root-end preparations using perpendicular apex resections. However, these instruments are more expensive, which could reduce their availability (8). This in vitro study evaluated the effect of different apicoectomy angles, instruments used in root-end preparation, and dental materials used in retrofilling on apical sealing. 


\section{MATERIAL AND METHODS}

This study was approved by the Scientific and Ethics Committee of the Dental School of the Pontifical Catholic University of Rio Grande do Sul, Porto Alegre, RS, Brazil. Eighty extracted human single-root teeth were collected (except lower incisors). Clinical crowns were sectioned at the cementum-enamel junction using a low-speed diamond saw (KG Sorensen Ltd., São Paulo, SP, Brazil) under continuous air/water spray to create a standardized root length of $16 \mathrm{~mm}$. Each root was submitted to radiographic examination to evaluate anatomy and apical morphology.

Roots were randomly assigned to one of 8 study groups (Table 1) and then submitted to root-end preparation and retrofilling, as described below.

Three radiographs were taken at different stages of specimen preparation: on sample selection; during endodontic treatment; and during retrofilling.

Specimens were instrumented up to file \#40 (Flexofile; Moyco Union Broach, York, PA, USA) following the stepback technique, and then were irrigated with $20 \mathrm{~mL}$ of $0.5 \% \mathrm{NaOCl}$ solution (Rio Química Ltda., São José do Rio Preto, SP, Brazil). Root canals were dried with absorbent paper points (Endo Points Ltda., Paraíba do Sul, RJ, Brazil) and filled using the lateral condensation technique with gutta-percha and Endofill (Dentsply, Petrópolis, RJ, Brazil). Then, the external root surfaces of all specimens were covered with 2 coats of nail polish (Niasi, Taboão da Serra, SP, Brazil).

Apical ends were cut $3 \mathrm{~mm}$ from the dental apex at angles of $45^{\circ}$ or $90^{\circ}$ using a $\# 4138$ diamond-coated bur (FAVA, São Paulo, SP, Brazil) under continuous air/ water spray. The root-end cavities were prepared with a \#2 round carbide bur (Dentsply/Maillefer, Ballaigues, Switzerland) at low-speed or with Satelec S12/S90D

Table 1. Study groups according to apicoectomy angle, instrument used in root-end preparation and material used as root-end filling.

\begin{tabular}{lccc}
\hline \multirow{2}{*}{$\begin{array}{l}\text { Apicoectomy } \\
\text { angle }\end{array}$} & $\begin{array}{c}\text { Instrument used } \\
\text { for root-end } \\
\text { cavity preparation }\end{array}$ & \multicolumn{2}{l}{ Root-end filling material } \\
\cline { 3 - 4 } & Ultrasonic tip & Group 1 & Amalgam \\
\hline $90^{\circ}$ & Carbide bur & Group 2 & Group 6 \\
& Ultrasonic tip & Group 3 & Group 7 \\
$45^{\circ}$ & Carbide bur & Group 4 & Group 8 \\
\hline
\end{tabular}

(diamond-coated) ultrasonic retrotip (Gnatus, Ribeirão Preto, SP, Brazil). The depth of root-end cavities was standardized at $3 \mathrm{~mm}$, and all the procedures were performed under continuous irrigation. The materials employed for retrofilling were zinc-free silver amalgam (Logic+; SDI, Bayswater, Vic., Australia) or gray MTA (Angelus, Londrina, PR, Brazil), prepared according to the manufacturer's instructions.

After retrofilling, specimens were air-dried and immediately immersed in $0.2 \%$ rhodamine $\mathrm{B}(\mathrm{pH}$ 7.0; Chemistry School, Federal University of Pelotas, Pelotas, RS, Brazil), except for the coronal portion. All roots were exposed to the same staining solution at room temperature for $24 \mathrm{~h}$. Then, teeth were washed for $1 \mathrm{~h}$ in tap water and roots were sectioned parallel to the apicoectomy using a low-speed saw (Labcut 1010; Extec, Enfield, CT, USA) with a $0.16 \mathrm{~mm}$-thick doublefaced diamond-coated disk ( 15 series HC-Buehler, Lake Bluff, IL, USA), under continuous irrigation, resulting in 3 apical sections, $1 \mathrm{~mm}$ far from each other, named as follows: A, more apical; B, intermediary; and C, more coronal. Only B slices were used, as the purpose was to evaluate dye penetration as deeper as possible, and C slices could not be read because there was endodontic filling material in several specimens. Sections were glued to millimeter-graph paper with ethyl cyanoacrylate (Super Bonder; Loctite S.A., São Paulo, SP, Brazil).

Each slice was digitized with an image-capture system connected to a stereoscopic microscope (Impac, Tokyo, Japan) at $25 \times$ magnification. The total area (TA), dye penetration area (DPA) and root-end filling area (FA) were measured quantitatively (in $\mathrm{mm}^{2}$ ) using the Image Tool 3.0 software (San Antonio Dental School, University of Texas Health Science Center, TX, USA) (Fig. 1).

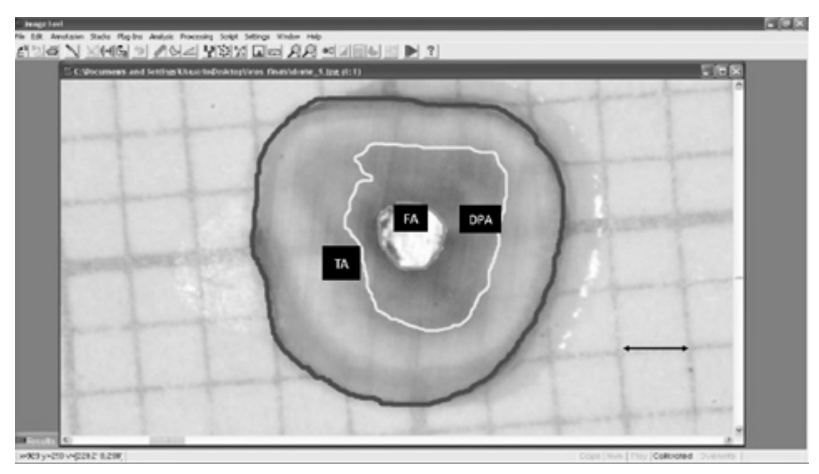

Figure 1. Measurement of dye penetration area (DPA), total area (TA), and area of root-end cavity filled with amalgam (FA). *Reference to perform evaluation $(1 \mathrm{~mm})$. 
As the TA of each tooth is different, larger teeth have the tendency to get more dyed, due to the larger number of dentinal tubules exposed to the dye solution. In order to avoid the effect of such root area variations in the different groups, relative measurement of dye penetration was used. Briefly, the dentinal area (DA) was calculated as TA minus FA. Then, the percentage of leakage area (PLA) was calculated as DPA/DA x 100. Measurements were made by 2 precalibrated examiners.

Statistical analysis of the results was performed using the Kruskal-Wallis and Mann-Whitney tests. Analyses were carried out using the Statistical Package for the Social Sciences (SPSS) version 13.0 for Windows.

\section{RESULTS}

Means and standard deviations obtained for dye penetration in each group are shown in Table 2.

Based on dye penetration results, root-end cavities were not completely sealed in any of the groups. The type of apicoectomy and instrument used in root-end preparation were not significant factors $(\mathrm{p}>0.05)$. Teeth filled with gray MTA showed lower leakage values $(p<0.05)$, independently of the combination of other factors (Table 3).

\section{DISCUSSION}

The interaction between root-end-preparation methods and materials used in retrofilling is an important factor for therapy success. The goals of apicoectomy

Table 2. Mean values and standard deviation of dye penetration obtained in each group.

\begin{tabular}{cc}
\hline Group & Mean (standard deviation) \\
\hline 1 & $18.81(6.87) \mathrm{a}$ \\
2 & $16.41(4.23) \mathrm{a}$ \\
3 & $18.51(5.36) \mathrm{a}$ \\
4 & $17.20(3.19) \mathrm{a}$ \\
5 & $28.01(7.48) \mathrm{b}$ \\
6 & $27.02(4.39) \mathrm{b}$ \\
7 & $30.97(11.16) \mathrm{b}$ \\
8 & $38.57(17.03) \mathrm{b}$ \\
\hline
\end{tabular}

Different letters indicate statistically significant difference among the groups $(\mathrm{p}<0.05)$. are to remove a persistent periapical lesion, prevent its recurrence, and promote tissue repair $(9,10)$. Promoting a secure seal is one of the main purposes of retrofilling and it can be assessed using an in vitro leakage test $(2,3,11)$.

Dye penetration tests are an easy and useful method in the assessment of retrofilling materials. If the materials are able to prevent the leakage of small molecules (tracer solutions) they potentially can also prevent the infiltration of larger substances, such as bacteria and their products $(11,12)$.

Among the different retrofilling techniques available, the $90^{\circ}$ bevel $3 \mathrm{~mm}$ from the apex exposes a lower number of dentinal tubules and provides a more effective removal of root ramifications (13). However, when the root-end cavity is prepared using a bur in a micro-handpiece, access to the canal is easier if the apex is resected at $30^{\circ}$ to $45^{\circ}$, mainly in the molar region (14). O'Connor et al. (15) showed no significant differences between the preparation with ultrasonic tips or handpiece in the sealing of retrofillings. Apicoectomy at a $90^{\circ}$ angle only became clinically possible with the use of ultrasonic retrotips in the preparation of root-end cavities (14). The use of ultrasonic retrotips is indicated when there is a substantial risk of root perforation or when access to the apex is limited (7). Despite of these potential differences, this study showed none significant difference in terms of microleakage when comparing the use of retrotips and carbide burs in a micro-handpiece. The area exposed after apicoectomy using both instruments was not significant. This is in agreement with the findings of Lin et al. (16), who demonstrated that a preparation

Table 3. Mean values of dye penetration obtained in each group.

\begin{tabular}{lccc}
\hline \multirow{2}{*}{$\begin{array}{l}\text { Apicoectomy } \\
\text { angle }\end{array}$} & $\begin{array}{c}\text { Instrument used } \\
\text { for root-end cavity } \\
\text { preparation }\end{array}$ & \multicolumn{2}{l}{ Root-end filling material } \\
\cline { 3 - 4 } & Ultrasonic tip & 18.81 & 28.01 \\
& & $(6.87) \mathrm{a}$ & $(7.48) \mathrm{b}$ \\
$90^{\circ}$ & Carbide bur & 16.41 & 27.02 \\
& & $(4.23) \mathrm{a}$ & $(4.39) \mathrm{b}$ \\
& & 18.51 & 30.97 \\
& Ultrasonic tip & $(5.36) \mathrm{a}$ & $(11.16) \mathrm{b}$ \\
& & 17.20 & 38.57 \\
& Carbide bur & $(3.19) \mathrm{a}$ & $(17.03) \mathrm{b}$ \\
\hline
\end{tabular}

*Different letters are indicating significant difference among the groups $(\mathrm{p}<0.05)$. 
depth of $3 \mathrm{~mm}$ provided a safe and effective sealing. Such finding indicates that retreatment to this depth provides an adequate apical seal, regardless of whether the resection angle is $90^{\circ}$ or $45^{\circ}$.

A review of clinical studies on dental materials used in retrofillings showed that amalgam was the most frequently used material in control groups; MTA was presented as a promising material for root-end filling $(2,3,7,9)$. Advantages associated with amalgam are its low cost, easier handling, and clinical success $(1,3)$. However, due to the growing concern on environmental contamination by hazardous metals, several other materials have been studied to replace amalgam (2).

It has been shown that MTA yields better results because it produces less leakage than other materials used in root-end filling (10). According to our results, MTA can be a more effective sealing retrofilling material than amalgam, independently of the root end preparation or instrument used for this preparation. In addition, MTA has other beneficial properties, such as easy handling, biocompatibility and lack of technical sensitive (17).

Within the limitations of this study, it may be concluded that: 1 . The angle of apicoectomy and the type of root-end preparation did not affect the degree of dye microleakage; 2 . The dental material used in retrofilling was the only factor significantly affecting microleakage results, with results favoring the use of MTA.

\section{RESUMO}

Este estudo in vitro avaliou o efeito de diferentes ângulos de apicectomia, instrumentos utilizados na retrocavitação e materiais odontológicos usados na retrobturação sobre selamento apical. Oitenta dentes unirradiculares, tratados endodonticamente, foram apicectomizados. Quarenta raízes tiveram seu ápice radicular seccionado com angulação de $45^{\circ}$ e a outra metade com angulação de $90^{\circ}$. Para cada tipo de apicectomia realizouse retrocavidades com broca esférica carbide $\mathrm{n}^{\circ} 2$ ou com retroponta ultra-sônica S12/90D. Cada subgrupo (apicectomia/ retrocavidade) foi retrobturado com MTA ou amálgama, sendo os espécimes imediatamente imersos no corante Rodamina B a $0,2 \%$ por $24 \mathrm{~h}$. O selamento apical foi avaliado com base na área transversal de dentina corada ao redor da retrobturação. Os dados foram submetidos á análise estatística utilizando os testes de Kruskal-Wallis e Mann-Whitney. Nenhum grupo foi capaz de selar totalmente a região apical. O tipo de material utilizado na retrobturação foi o único fator que mostrou significativa diferença no selamento apical em relação à infiltração de corante.

\section{ACKNOWLEDGEMENTS}

M.G.O has a scholarship (1D) from the National Council for Scientific and Technological Development (CNPq). We would also thank the Center for Development and Control of Biomaterials (CDC Bio) at Federal University of Pelotas.

\section{REFERENCES}

1. Costa AT, Konrath F, Dedavid B, Weber JB, de Oliveira MG. Marginal adaptation of root-end filling materials: an in vitro study with teeth and replicas. J Contemp Dent Pract 2009;10:75-82.

2. Pereira CL, Cenci MS, Demarco FF. Sealing ability of MTA, Super-EBA, Vitremer and amalgam as root-end filling materials. Braz Oral Res 2004;18:317-321.

3. Xavier CB, Weismann R, Oliveira MG, Demarco FF, Pozza DH. Root-end filling materials: apical microleakage and marginal adaptation. J Endod 2005;31:539-542.

4. Gagliani MM, Gorni FG, Strohmenger L. Periapical resurgery versus periapical surgery: a 5-year longitudinal comparison. Int Endod J 2005;38:320-327.

5. Winik R, Araki AT, Negrão JA, Bello-Silva MS, Lage-Marques JL. Sealer penetration and marginal permeability after apicoectomy varying retrocavity preparation and retrofilling material. Braz Dent J 2006;17:323-327.

6. Costa AT, Post LK, Xavier CB, Weber JB, Gerhardt-Oliveira M. Marginal adaptation and microleakage of five root-end filling materials: an in vitro study. Minerva Stomatol 2008;57:295-300.

7. Tsesis I, Rosen E, Schwartz-Arad D, Fuss Z. Retrospective evaluation of surgical endodontic treatment: traditional versus modern technique. J Endod 2006;32:412-416.

8. Bernardes RA, Souza Junior JV, Duarte MAH, Moraes IG, Bramante CM. Ultrasonic chemical vapor deposition-coated tip versus high-and low-speed carbide burs for apicoectomy: time required for resection and scanning electron microscopy analysis of the root-end surfaces. J Endod 2009;35:265-268.

9. Johnson BR. Considerations in the selection of a root-end filling material. Oral Surg Oral Med Oral Pathol Oral Radiol Endod 1999;87:398-404.

10. Baek SH, Plenk Jr H, Kim S. Periapical tissue responses and cementum regeneration with amalgam, Super Eba, and MTA as root-end filling materials. J Endod 2005;31:444-449.

11. Vogt BF, Xavier CB, Demarco FF, Padilha MS. Dentin penetrability evaluation of three different dyes in root-end cavities filled with mineral trioxide aggregate (MTA). Braz Oral Res 2006;20:132-136.

12. Aqrabawi J. Sealing ability of amalgam, Super EBA cement, and MTA when used as retrograde filling materials. Braz Dent J 2000;188:266-268.

13. Gilheany PA, Figdor D, Tyas MJ. Apical dentin permeability and microleakage associated with root end resection and retrograde filling. J Endod 1994;20:22-26.

14. Kellert M, Solomon C, Chalfin H. A modern approach to surgical endodontics: ultrasonic apical preparation. NY State Dent J 1994;60:25-28.

15. O'Connor RP, Hutter JW, Roahen JO. Leakage of amalgam and Super-EBA root-end fillings using two preparation techniques and surgical microscopy. J Endod 1995;21:74-78.

16. Lin S, Platner O, Metzger Z, Tsesis I. Residual bacteria in root apices removed by a diagonal root-end resection: a histopathological evaluation. Int Endod J 2008;41:469-475.

17. Goldim E Jr, Kim S, de Souza-Filho FJ. An investigation of microleakage from root-end fillings in ultrasonic retrograde cavities with or without finishing: a quantitative analysis. Oral Surg Oral Med Oral Pathol Oral Radiol Endod 2005;99:755-760.

Accepted August 2, 2010 